\title{
FUNGSI PENDIDIKAN DALAM PERUBAHAN SOSIAL KONTEMPORER
}

\author{
Madekhan \\ madekhan@unisla.ac.id \\ PAI Program Pasca Sarjana, Universitas Islam Lamongan
}

\begin{abstract}
Abstrak
Perubahan sosial di negara-negara berkembang, termasuk Indonesia, tercatat begitu dinamis, termasuk di dalamnya inovasi teknologi digital saat ini. Interelasi pendidikan dengan perubahan sosial dalam kajian berbasis kepustakaan ini dipusatkan pada empat sub kajian dimana ditemukan bahwa: 1) perubahan lingkungan menuntut adaptasi di internal masyarakat. Sementara pengaruh eksternal menyebabkan diterimanya nilai-nilai dan tata tata perilaku baru. 2). Fungsi pendidikan khususnya pada upaya membentuk perubahan sosial yang terpola atau direncanakan. Melalui pendidikan dirancang arah perubahan sosial atas dasar prediksi-prediksi ilmiah, sehingga akibatnya bisa diramalkan. 3) Implikasinya, pendidikan - melalui pendidiknya bisa menjadi alat kontrol sosial yang efektif dalam membentuk masyarakat baru. 4) terdapat prinsip - prinsip pengajaran baru yang wajib untuk diterapkan pendidik di era transformasi digital saat ini.
\end{abstract}

Kata Kunci: Fungsi pendidikan, sosial kontemporer

\section{PENDAHULUAN}

Deskripsi yang luas dan beragamnya analisis teoritis akan menjadi bagian ketika kita mendiskusikan perubahan sosial, baik dari sisi penyebab maupun kecenderungan prediktifnya. Kiranya tidak ada ahli yang berani menyederhanakan penjelasan dan analisis perubahan sosial, seperti halnya ditunjukkan Professor W.J. Sprott, dimana untuk mampu secara lengkap menjelaskan perubahan sosial, dia sampai menghabiskan 700 sampai 800 halaman (Ivor Morrish, 2017). Perubahanperubahan dalam masyarakat terjadi di semua bidang, yaitu di bidang-bidang: ekonomi, politik, bahasa, kesenian, hiburan, adat dan lain-lain. Dalam beberapa abad tertentu, perubahan ini terjadi dengan sangat lambat sehingga tidak terasa oleh manusia, oleh karenanya orang lalu berpendapat, bahwa "waktu tetap tenang" dan "semua berlangsung seperti biasa, seperti sekarang". Tetapi terdapat juga abad-abad, dimana terjadi perubahan-perubahan yang sangat cepat dan menyolok pada semua bidang. Maka berkatalah orang-orang: "kita tidak mengerti akan waktu lagi". Banyak orang yang menjadi tidak tenang dan menolak semua perubahan-perubahan.

Perubahan sosial di negaranegara berkembang, termasuk Indonesia, tercatat begitu dinamis, paling tidak sejak 50 tahun terakhir. Perencanaan perubahanperubahan sosial yang sangat menyolok di negara-negara berkembang dengan payung modernisasi, diterjemahkan oleh banyak pemerintah negara dunia ketiga dengan mengadakan dan merencanakan usahausaha pembangunan (development). Perubahan-perubahan itu tidak berasal dari alam, tetapi dari manusia dan masyarakat. Perubahan-perubahan ini tidak hanya terjadi pada individu-individu, melainkan pada seluruh masyarakat, oleh karenanya kita sebut perubahan sosial. Perubahan sosial meliputi juga perubahan-perubahan dalam teknik dan ekonomi. Apakah kita menjadi korban dari perubahan-perubahan itu ataukah kita dapat menarik keuntungan? Apakah kita sebagai penonton saja atau pemain dalam prosesproses perubahan sosial itu? Ini sangat tergantung pada, apakah kita mengerti akan arti dan tujuan dari perubahanperubahan yang terjadi pada saat ini. 
Kita melihat bahwa, suatu penemuan mengakibatkan perubahanperubahan pada beberapa bidang dalam kehidupan masyarakat. Sejak tahun 1750 , banyak terjadi penemuan-penemuan yang mengubah cara hidup pada semua masyarakat di dunia: Masin uap, alat tenun mesin, listerik, motor bensin dan motor diesel, kereta api, pesawat terbang, mesin cetak, radio, foto, televisi, komputer, reaktor atom, roket-roket, obat antibiotika, bahan sintesis, pupuk buatan. Ini hanyalah sebagian kecil dari penemuan saja untuk

\section{PEMBAHASAN}

\section{Konsepsi, Adopsi dan Resistensi}

Untuk memahami perubahan pada kehidupan seseorang, kita harus memahami hal-hal terkait pola-pola perubahan sosial yang lebih luas.Perubahan pada kehidupan individu dan keluarga dipengaruhi dan bentuk oleh kompleksitas perubahan ekonomi, teknologi, urbanisasi, maupun pendidikan. Melalui sosiologi pendidikan, kita akan memiliki kapasitas referensi dan perangkat analisis yang memadai untuk menafsirkan dan memahami mengapa terdapat perbedaan orientasi pendidikan antar generasi: baby boomers, Gen X, Gen Y, millennials dan Gen Z, dari faktor, pola maupun implikasi perubahan sosialnya. disebut di sini, belum termasuk di dalamnya inovasi teknologi digital saat ini.

Paling tidak, kajian berikut berupaya mengidentifikasi bagaimana fungsi-fungsi pendidikan dijalankan dalam perubahan sosial. Melalui studi eksplorasi kepustakaan, penulis membagi kajian ke dalam empat sub-bahasan; 1), konsepsi, adopsi dan resistensi perubahan sosial, 2) relasi fungsional pendidikan dan perubahan sosial, 3) fungsi kontrol sosial pendidikan, 4) reposisi pendidik di era transformasi digital.

Perubahan sosial pada dasarnya merupakan perubahan dari masa ke masa, yang terjadi dalam nilai-nilai budaya, pola perilaku, struktur dan fungsi masyarakat. John Gillin et al (1948) berpendapat bahwa perubahan sosial diartikan sebagai variasi dari cara-cara hidup yang telah diterima, baik karena perubahanperubahan kondisi geografis, kebudayaan material, komposisi penduduk, ideologi maupun karena adanya difusi ataupun penemuan-penemuan baru dalam masyarakat. Menurut Harper; perubahan sosial adalah perubahan mendasar atau signifikan pada perubahan sosial dari waktu ke waktu, dimana pada tingkat struktur bisa digambarkan pada Tabel berikut:

Tabel 1. Perubahan Struktural

\begin{tabular}{l}
\hline STRUCTURE LEVEL \\
Kelompok Kecil \\
Organisasi \\
Pranata \\
Masyarakat \\
Global \\
\hline
\end{tabular}

CHANGES
Peran, Struktur komunikasi, pengaruh, clique.
Struktur, hirarki, otoritas, produktivitas
Ekonomi, Agama, Keluarga, Pendidikan
Stratifikasi sosial, Demografi, Kekuasaan
Evolusi, Hubungan internasional, modernisasi dam pembangunan

Menurut William A. Haviland (1985), faktor terjadinya perubahan sosial cukup beragam. Terjadinya perubahan lingkungan yang menuntut perubahan sosial yang bersifat adaptif merupakan faktor internal masyarakat. Sementara faktor eksternal, terutama ditandai dengan terjadinya kontak dengan bangsa lain dimana menyebabkan diterimanya kebudayaan asing sehingga terjadilah perubahan dalam nilai-nilai dan tata kelakuan yang ada. Maka secara garis besar, perubahan sosial bisa disebabkan faktor-faktor:

1. Bertambah dan atau berkurangnya jumlah penduduk; 
2. Adanya inovasi teknologi;

3. Konflik sosial;

4. Suksesi politik

5. Perubahan lingkungan alamiah;

6. Pengaruh kebudayaan masyarakat lain.

Tidak ada masyarakat yang berhenti perkembangannya, karena setiap masyarakat mengalami perubahan yang terjadi secara lambat atau cepat. Perubahan yang terjadi pada kelembagaan masyarakat akan diikuti dengan perubahan- perubahan pada kelembagaan sosial lainnya. Perubahan-perubahan sosial yang cepat biasanya mengakibatkan disorganisasi yang bersifat sementara karena berada dalam proses penyesuaian diri. Disorganisasi akan diikuti oleh reorganisasi yang mencakup pemantapan kaidah dan nilai yang baru. Perubahan tidak dapat dibatasi pada bidang-bidang kebendaan atau bidang spriritual saja, karena keduanya memiliki kaitan timbal balik yang sangat kuat.

Telah banyak dibicarakan bahwa masyarakat kita saat ini tidak pernah lepas dari gejala perubahan. Namun karena gejala tersebut memiliki intensitas yang begitu kuat maka banyak pihak yang mengkhawatirkan ketangguhan "daya tangkal" nilai-nilai masyarakat yang telah mapan menjadi goyah lalu perlahan lahan akan mengalami pemudaran. Perubahan dalam masyarakat memang telah ada sejak jaman dulu. Namun dewasa ini perubahanperubahan tersebut berjalan dengan sangat cepat. Hal ini membingungkan manusia yang menghadapinya. Perubahanperubahan mana sering berjalan secara konstan dan terikat dengan waktu dan tempat. Akan tetapi karena sifatnya berantai, maka perubahan terlihat berlangsung terus, meskipun diselingi keadaan di mana masyarakat yang mengalami perubahan.

Antar kelompok masyarakat memiliki perbedaan dalam adopsi setiap perubahan ataupun inovasi baru. Ada masyarakat yang sangat cepat mengadopsi suatu perubahan, ada yang lambat bahkan ada yang sangat skeptik, di samping yang terjadi pada kebanyakan anggota masyarakat umumnya. Hal ini terjadi, karena anggota masyarakat memiliki perbedaan kesiapan untuk menerima perubahan itu, sebagai akibat dari adanya variasi pengetahuan, cara berpikir, sikap, variasi personalitas, pengalaman, selain kesesuaiannya antara nilai yang ia miliki dengan nilai baru yang ditawarkan.

Tabel 2. Faktor Adopsi dan Resistensi Perubahan Sosial

\begin{tabular}{|c|c|c|}
\hline Jenis & Faktor & Pengaruh \\
\hline Budaya & Inersia Budaya & $\begin{array}{l}\text { Membentuk masyarakat yang menutup diri } \\
\text { dari pengaruh budaya luar. }\end{array}$ \\
\hline Psikologi Sosial & $\begin{array}{l}\text { Ketakutan pada akibat adanya penerapan } \\
\text { hal-hal baru. }\end{array}$ & $\begin{array}{l}\text { Ketakutan dan kecemasan terhadap adanya } \\
\text { perilaku dan praktek yang baru akan } \\
\text { merusak tata sosial (social order). }\end{array}$ \\
\hline Ideologi Politik & Kepentingan Pribadi (Vested Interests) & $\begin{array}{l}\text { Adanya kepentingan penguasan / kelompok } \\
\text { dominan untuk mempertahankan praktek } \\
\text { lama demi keuntungan pribadi atau } \\
\text { melanggengkan kuasa kelompoknya. }\end{array}$ \\
\hline $\begin{array}{l}\text { Lingkungan } \\
\text { Geografis }\end{array}$ & Tingkat keterisolasian & $\begin{array}{l}\text { Rendahnya intensitas interaksi masyarakat } \\
\text { dengan dunia luar akibat terbatasanya sarana } \\
\text { komunikasi dan transportasi. }\end{array}$ \\
\hline
\end{tabular}

Perubahan di negara-negara berkembang misalnya, tentu berbeda dengan yang ada di negara maju (barat). Di negara-negara maju, perubahan diisi suatu dinamika perubahan sosial dan nilai yang terkandung dalam pendidikan. Di sisi lain, walaupun banyak usaha yang dilakukan negara-negara berkembang, tetap saja pola pendidikan yang bernuansa kolonial belum bisa dihilangkan. Perubahan ini memang proses yang susah dan tidak heran hanya sedikit sistem 
pendidikan yang secara signifikan berubah sesuai fungsinya di negara berkembang. Karena kita juga tidak bisa begitu saja melepaskan diri begitu saja dengan perkembangan di luar sana.

Selain karakteristik yang dimiliki oleh seseorang atau suatu masyarakat, faktor referensi atau panutan juga berperanan penting dalam adopsi perubahan itu. Unsur-unsur yang dapat dijadikan referensi oleh seseorang atau masyarakat terhadap proses adopsi perubahan itu di antaranya adalah, (1) orangtua (2) pemuka masyarakat baik formal mupun non-formal, (3) teman dekat, (4) figur idola, dan (5) orang yang paling berpengaruh terhadap diri seseorang. Unsur-unsur no. 1, 2, dan 3, dapat ditunjuk dengan jelas dalam masyarakat. Akan tetapi unsur figur idola dan unsur orang yang paling berpengaruh terhadap diri seseorang sangat subjektif. Figur-fiigur itu dapat berwujud bintang film, tokoh masyarakat, sifat heroisme, atau yang lain, yang pada dasarnya dapat berbentuk karakteristik atau aktualisasi dari figur itu yang dinilai sesuai dengan nilai yang dimilikinya, karena baik pola maupun kecepatan seseorang atau suatu masyarakat menerima suatu perubahan pada dasarnya adalah berbeda. Perbedaan ini yang dapat menghasilkan kesenjangan tata nilai di dalam masyarakat, lebih-lebih lagi dalam situasi di mana kompleksitas perubahan itu semakin meluas dan perubahan itu terjadi sangat cepat.

Dalam perspektif perubahan budaya manusia melekat dengan perubahan alam dan jaman, maka pada era teknologi, suatu masyarakat akan ketinggalan apabila masyarakat itu tidak menerapkan teknologi dalam tatanan hidup mereka. Bahkan teknologi telah terbukti membawa tingkat efisiensi dan kemakmuran masyarakat, karena sifat dari teknologi itu yang pada dasarnya memburu perolehan nilai tambah. Sementara perubahan budaya itu pada dasarnya adalah untuk adaptasi terhadap perubahan alam dan jaman agar manusia tetap mampu mempertahankan eksistensi hidup mereka. Meskipun kekayaan sumber daya alam bukan faktor penentu terhadap kemajuan suatu masyarakat dibandingkan dengan kekayaan sumber daya manusia tetapi semakin berkurangnya daya dukung potensi sumber daya alam dibanding dengan tuntutan kebutuhan manusia yang jumlahnya semakin besar tetap akan berdampak terhadap terjadinya perubahan pola hidup manusia. Apabila produk dan jasa yang menjadi ukuran kekuatan suatu masyarakat potensial bagi masyarakat tertentu, maka mereka itu yang akan mampu menguasai pasar, yang akhirnya merekalah yang akan mampu mempertahankan eksistensi hidup mereka. Akhirnya penguasaan teknologi yang akan menghasilkan keunggulan suatu bangsa.

\section{Relasi Fungsional Pendidikan}

\section{Prof. WJH Sprott}

membagi perubahan sosial menjadi dua, yaitu perubahan episode (episodic change) dan perubahan terpola (pattern change). Perubahan episode, berlangsung sewaktuwaktu, dikarenakan peristiwa-peristiwa tertentu yang tidak diperkirakan sebelumnya, bisa jadi akibat kerusuhan, atau penemuan, bencana alam, dan sebagainya. Sedangkan perubahan terpola, berlangsungnya memang direncanakan, diprogramkan, sebagaimana yang dilakukan melalui upaya pembangunan ataupun perubahan kebijakan sistem pendidikan. Perubahan-perubahan itu sendiri memang dirancang atas dasar prediksi-prediksi, sehingga dampak atau akibatnya bisa diramalkan secara cermat.

Salah satu bentuk perubahan yang terpola adalah upaya masyarakat untuk mempertahankan eksistensinya dengan penguasaan teknologi. Karena itu unsur kreativitas, unsur kemandirian dalam kebersamaan (kolaborasi), unsur produktivitas, menjadi faktor yang sangat penting untuk membangun budaya hidup teknologis saat ini. Kebutuhan perubahan 
sebagai konsekuensi dari dinamisnya perkembangan teknologi informasi, salah satunya adalah perubahan sistem pendidikan. Dunia pendidikan semakin dituntut menampilkan tata laksana yang baik yang didukung oleh kurikulum adaptif maupun fleksibel. Sekolah misalnya, didorong untuk mampu mendorong terjadinya perubahanperubahan sosial budaya yang adaptif terhadap teknologi digital, khususnya di era Revolusi Industri 4.0.

Pendidikan formal, misalnya di sekolah harus berbenah bagaimana mengajarkan kepada anak didik berbagai macam pengetahuan, keterampilan dan karakter yang dibutuhkan oleh para siswa sebagai masyarakat masa depan. Pendidikan menemukan signifikasinya manakala mampu memberikan kerangka nilai-nilai spiritual, kemanusiaan, dan terutama dalam membuka pikiran peserta didik untuk mampu menerima hal-hal baru dengan cara berpikir secara ilmiah. Pengelolaan pranata pendidikan secara baik dan adaptif terhadap perubahan sosial, maka bukan hanya sekedar dapat mengajarkan pengetahuan, kemampuan ilmiah, skill, serta nilai-nilai tertentu yang dibutuhkan siswa, namun pendidikan mampu lebih dari itu juga mendidik anak agar dapat berpikir secara obyektif. Dengan kemampuan penalaran seperti itu, pendidikan baik formal maupun informal akan dapat membekali siswa kemampuan beradaptasi dan mereproduksi kebudayaan masyarakatnya sesuai kebutuhankebutuhan jamannya. Di sinilah kira-kira peranan atau faktor pendorong pendidikan untuk berlangsungnya perubahanperubahan dalam masyarakat.

Pendidikan yang mampu menghasilkan manusia-manusia kreatif menjadi tuntutan dalam pola pendidikan umum saat ini. Banyaknya media yang dapat berperan sebagai sumber informasi pendidikan bagi generasi bangsa saat ini, maka konsep pendidikan perlu mengalami pergeseran. Pada titik demikian, pendidikan tidak sekedar sebagai sebagai usaha yang disengaja lagi akan tetapi lebih menjadi kondisi apapun yang dampaknya dapat menyebabkan terjadinya perubahan nilai-nilai manusia.

Kondisi dalam kehidupan keluarga, kondisi yang terjadi dalam masyarakat luas sebagai panggung pentas budaya bangsa kondisi yang ditampilkan oleh berbagai media baik cetak maupun elektronika, kondisi yang terjadi di sekolah kesemuanya secara bersama sama mewujudkan terjadinya proses pendidikan bagi generasi bangsa kita. Baik dipandang dari dimensi tuntutan kualitas manusia masa kini dan masa datang maupun dari kondisi pendidikan yang semakin kompleks dan multidimensional itu, maka pendidikan kita telah saatnya lebih banyak memberi kesempatan anak-anak kita mengaktualisasikan diri dalam kondisi yang terkontrol baik di rumah maupun di sekolah untuk mengimbangi kondisi yang tidak terkontrol dalam kehidupan di masyarakat luas yang justru tarik menarik pengaruhnya terhadap proses pendidikan formal semakin besar. Peran pendidikan orang tua dan pendidikan sekolah dituntut semakin besar, apabila kita ingin generasi bangsa kita tidak mengalami pemudaran nilai-nilai budaya bangsa kita yang akan menjalar kepada pemudaran rasa kebangsaan kita, dengan lebih besar memberikan kesempatan kepada mereka untuk mengaktualisasikan diri mereka masing-masing.

Di dalam dinamika perubahan sosial yang sedemikian deras, maka penyelenggaraan pendidikan juga harus memunculkan suatu kontinyuitas adaptasi paradigma. Berkaca pada Teori Brofenbrenner yang menitik beratkan pada faktor lingkungan (ekologi), maka perilaku seseorang peserta didik tidak berdiri sendiri, melainkan merupakan dampak dari interaksi orang yang bersangkutan dengan lingkungan di luarnya.

Adapun lingkungan di luar diri individu peserta didik oleh Brofenbrenner 
di bagi dalam beberapa lingkaran yang berlapis-lapis (1979) :

1. Lingkaran pertama adalah yang paling dekat dengan pribadi anak, yaitu lingkaran sistem mikro yang terdiri dari keluarga, sekolah, guru, tempat penitipan anak, teman bermain, tetangga, rumah, tempat bermain dan sebagainya yang sehari-hari ditemui oleh anak.

2. Lingkaran kedua adalah interaksi antar faktor-faktor dalam sistem mikro (hubungan orangtua-guru, orang tuateman, antar teman, guru-teman dsb.) yang dinamakannya sistem meso.

3. Di luar sistem mikro dan meso, ada lingkaran ketiga yang disebut sistem exo, yaitu lingkaran lebih luar lagi, yang tidak langsung menyentuh pribadi anak, akan tetapi masih besar pengaruhnya, seperti keluarga besar, polisi, Komite sekolah, dokter, koran, televisi dsb.

4. Akhirnya, lingkaran yang paling luar adalah sistem makro, yang terdiri dari ideologi negara, pemerintah, tradisi, agama, hukum, adat, budaya dsb.

Singkatnya, dengan mengikuti teori Brofenbrenner, akan menguraikan bagaimana sistem pendidikan yang terjadi di dunia, khususnya di Indonesia, harus terus memperhatikan dan tanggap dengan perubahan yang terjadi pada sistem-sistem lain yang berpengaruh pada kepribadian peserta didik. Dengan mengikuti arus diferensiasi dan spesialisasi pendidikan selama dekade-dekade terakhir, ada dua perubahan mendasar yang terlihat nyata, yaitu:

a. Adanya spesialisasi dan ekspansi persekolahan, didukung dengan kemampuan pendanaan publik menyebabkan peran negara semakin menurun, khususnya pada tingkat pendidikan dasar dan menengah.

b. Di satu sisi Pemerintah semakin menyadari pentingnya pendidikan formal di dalam sustainibilitas pembangunan sosial, di sisi lain negara menghadapi dilema prakmatisme pendidikan untuk pemenuhan tenaga kerja sektor industri,

c. Transformasi teknologi digital mendorong efisiensi proses belajar mengajar sehingga memunculkan lahirnya berbagai inovasi sosial.

Juga jelas, bahwa sistem pendidikan senantiasa saling berinteraksi dan mempengaruhi dengan sistem-sistem lainnya di masyarakat. Terutama sistem dan garis politik suatu bangsa atau negara, termasuk faktor penting yang mempengaruhi "posisi" dan aktualisasi peranan sistem pendidikan di masyarakat. Dengan demikian, sistem pendidikan sesungguhnya ditantang untuk tidak menjadi "mesin sosial" yang ketinggalan zaman di dalam mengikuti gerak perubahan masyarakat dimana dia hidup. Di sisi lain, sistem pendidikan ditantang untuk menggunakan momentum perkembangan masyarakat guna menunjukkan "kehandalannya" selaku agen pembaruan dan kontrol perubahan sosial.

\section{Kontrol Sosial Pendidikan}

Di dalam percakapan sehari-hari, sistem pengendalian sosial atau social control seringkali diartikan sebagai pengawasan oleh masyarakat terhadap jalannya pemerintahan khususnya pemerintah beserta aparaturnya. Asumsi tersebut memang ada benarnya namun dalam pengertian yang mendasar pengendalian sosial tidak hanya berhenti pada pengertian itu saja. Arti sesungguhnya pengendalian sosial jauh lebih luas, karena pada pengertian tersebut tercakup segala proses, baik yang direncanakan maupun tidak, yang bersifat mendidik, mengajak atau bahkan memaksa warga-warga masyarakat agar mematuhi kaidah-kaidah dan nilai sosial yang berlaku.

Jadi pengendalian sosial dapat dilakukan oleh individu terhadap individu lainnya (misalnya seorang ibu mendidik 
anak-anaknya agar menyesuaikan diri pada kaidah-kaidah dan nilai-nilai yang berlaku) atau mungkin dilakukan oleh individu terhadap suatu kelompok sosial (umpamanya, seorang dosen di Perguruan Tinggi memimpin beberapa orang mahasiswa dalam kegiatan kuliah kerja lapangan). Seterusnya pengendalian sosial dapat dilakukan oleh kelompok terhadap kelompok lainnya, atau oleh suatu kelompok terhadap individu. Itu semua merupakan proses pengendalian sosial yang dapat terjadi dalam kehidupan seharihari, meskipun seringkali manusia tidak menyadari.

$$
\text { Dengan demikian secara }
$$

mendasar pengendalian sosial bertujuan untuk mencapai keserasian antara stabilitas dengan perubahan-perubahan dalam masyarakat atau suatu sistem pengendalian bertujuan untuk mencapai keadaan damai melalui keserasian antara kepastian dengan keadilan. Menurut Soekanto (1990) sifat pengendalian sosial bisa bersifat preventif atau represif. Preventif merupakan suatu usaha pencegahan terhadap munculnya gangguan-gangguan pada keserasian antara kepastian dengan keadilan. Usahausaha preventif dijalankan melalui proses sosialisasi, pendidikan formal dan informal. Dari penegasan tersebut bisa dikatakan bahwa aktivitas pendidikan baik itu di sekolah maupun di luar sekolah merupakan salah satu alat pengendalian sosial yang telah melembaga baik itu pada masyarakat tradisional maupun yang sudah modern. Sehingga dalam hal ini pengertian pendidikan merupakan proses pengendalian secara sadar di mana perubahan-perubahan tingkah laku dihasilkan dari di dalam diri orang itu melalui pergulatan sosialnya. Dari pandangan ini pendidikan adalah suatu proses yang dimulai pada waktu lahir dan berlangsung sepanjang hidup. Pengertian pengendalian secara sadar ini berarti adanya tingkat-tingkat kesadaran dari tujuan yang hendak di dapat.
Sementara itu, sebagaimana uraian penjelasan pada halaman - halaman terdahulu bahwa di era modern ini lembaga pendidikan juga mengalami proses transformasi baik itu pola kegiatan, tata nilai, bentuk dan organisasi perannya di masyarakat. Secara spesifik telah memunculkan lembaga sekolah sebagai manifestasi wujud orientasinya. Sehingga pada segi sosialnya sekolah memegang peranan penting dalam sosialisasi anakanak. Sebagai salah satu upaya pengendalian sosial ada empat cara yang dapat digunakan sekolah yakni :

a. Transmisi kebudayaan, termasuk norma-norma, nilai-nilai dan informasi melalui pengajaran secara langsung, misalnya tentang falsafah negara, sifatsifat warga negara yang baik, struktur pemerintahan, sejarah bangsa dan sebagainya

b. Mengadakan kumpulan-kumpulan sosial seperti perkumpulan sekolah, Pramuka, kelompok olah raga, dan sebagainya yang dapat memberikan kesempatan kepada anak-anak untuk mempelajari dan mempraktikkan berbagai keterampilan sosial.

c. Memperkenalkan anak dengan tokohtokoh yang dapat dijadikan anak sebagai figur tauladannya. Dalam hal ini guru-guru dan pemimpin sekolah memegang peranan yang penting.

a. Menggunakan tindakan positif dan negatif untuk mengharuskan murid mengikuti tata perilaku yang layak dalam bimbingan sosial. Yang termasuk dalam tindakan positif ialah pujian, hadiah dan sebagainya sedangkan cara yang negatif berupa hukuman, celaan dan sebagainya.

Ada para pendidik yang menaruh kepercayaan yang besar sekali akan kekuasaan pendidikan dalam membentuk masyarakat baru. Oleh karena itu setiap anak diharapkan memasuki sekolah dan dapat diberikan ide-ide baru tentang masyarakat yang lebih indah daripada yang sudah-sudah. Sekolah dapat 
merekonstruksi atau mengubah dan membentuk kembali masyarakat baru.

Apakah harapan itu akan terpenuhi? Dapat dipertanyakan. Pihak yang berkuasa di suatu negara pada umumnya menggunakan sekolah untuk mempertahankan dasar-dasar masyarakat yang ada. Perubahan yang asasi tak akan terjadi tanpa persetujuan pihak yang berkuasa dan masyarakat. Sekolah tak dapat melepaskan diri dari masyarakat tempat ia berada dan dari kontrol pihak yang berkuasa. Sekolah hanya dapat mengikuti perkembangan dan perubahan masyarakat dan tak mungkin mempelopori atau mendahuluinya. Jadi tidak ada harapan sekolah dapat membangun masyarakat baru lepas dari proses perubahan sosial yang berlangsung dalam masyarakat itu.

\section{Reposisi Pendidik di Era Transformasi Digital}

Belajar dari pengalaman berbagai dunia, tentu saja sekolah dapat digunakan oleh yang berkuasa untuk mengadakan perubahan-perubahan radikal yang diinginkan oleh pihak yang berkuasa itu, seperti Hitler di Jerman, Partai Komunis di Uni Soviet, Jepang di daerah jajahannya dan sebagainya. Sistem pendidikan adalah alat yang ampuh untuk mengindoktrinasi generasi muda agar menciptakan suatu masyarakat menurut keinginan mereka yang mengontrolnya. Perubahan kekuasaan dalam suatu negara, misalnya oleh golongan yang menganut ideologi lain akan memanfaatkan sekolah sebagai alat untuk membangun masyarakat baru menurut ideologi mereka.

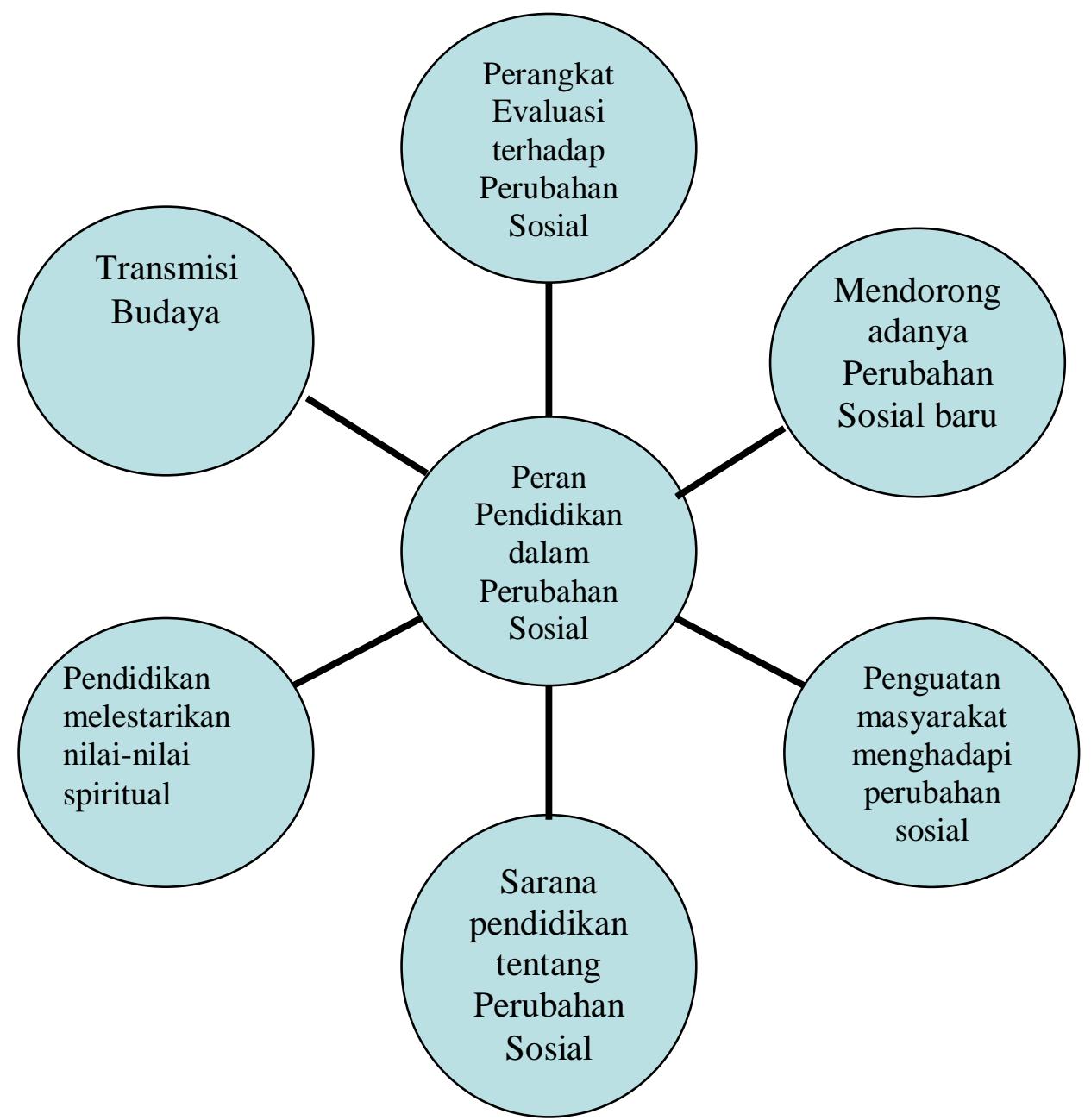

Gambar 1. Peran Pendidikan Dalam Perubahan Sosial 
Untuk para figur pendidik, bagaimana menghadapi perubahan sosial akibat era revolusi industri 4.0 yang bersifat disruptif saat? Era dimana bermunculan banyak sekali inovasi inovasi yang tidak terlihat, tidak disadari oleh organisasi mapan sehingga mengganggu jalannya aktivitas tatanan sistem lama atau bahkan menghancurkan sistem lama tersebut. Contoh - contoh sederhana seperti yang kita ketahui adalah menurunnya performa bisnis dari armada taksi pemimpin pasar yang harus mengakui keberadaan apps-based transportation service macam Grab, GoJek, dan Uber. Bentrokan - bentrokan terjadi, dan yang paling baru adalah mogoknya armada angkot di Bogor (sebagai salah satu kota yang angkotnya banyak) karena merasa tersaingi oleh transportasi berbasis aplikasi ini.

$$
\text { Kebanyakan kasus }
$$

kasus disruption, dibahas di sektor bisnis, namun, jarang sekali dibahas di sektor pendidikan. Padahal paling kasat mata adalah terganggunya prospek Lembaga Bimbingan Belajar (LBB) luar jaringan (luring) yang telah mapan, sebagai dampak berkembang pesatnya LBB dalam jaringan (daring), seperti quipper dan ruang guru. Menjadi cukup relevan ketika Edmund W. Gordon (2019) menyatakan bahwa "adalah tugas guru untuk mendidik, mendidik

\section{KESIMPULAN}

Kajian terhadap empat kerangka fungsi pendidikan dalam perubahan sosial kontemporer menunjukkan bahwa:

a. Perubahan lingkungan internal menuntut adaptasi masyarakat.

Sementara pengaruh eksternal menyebabkan diterimanya nilai-nilai dan tata tata perilaku baru.

b. Fungsi pendidikan khususnya pada upaya membentuk perubahan sosial yang terpola atau direncanakan. Melalui pendidikan dirancang arah perubahan sosial atas dasar prediksi-prediksi siswanya menghadapi perubahan, mendidik mereka menjalani perubahan, untuk secara terarah mendidik mereka merencanakan revolusi. Jika perlu mendidik siswanya menjalani suatu zaman revolusi yang lebih disruptif.

Deans for Impact sebuah organisasi yang terdiri dari pendidik senior dan pengkader pendidik - pendidik baru, menerbitkan report "Practice with Purpose" yang berisikan prinsip - prinsip wajib untuk diterapkan pendidik dalam disruptive era. Lantas apa saja prinsip yang harus dipegang pendidik di era disruptive? (mengutip dari Arryrahmawan.net)

1. Push Beyond Comfort Zone (Keluar dari zona nyaman)

2. Works Toward Well Defined, Specific Goals (Bekerja dengan target atau capaian yang jelas)

3. Focus Intently on Impactful Activities (Fokus memberikan aktivitas yang bermakna dan berdampak)

4. Receive and Respond High Quality Impact (Menerima dan Memberikan feedback berkualitas)

5. Develop Mental Model of Expertise (Membentuk mental model seorang berkualifikasi ahli)

ilmiah, sehingga akibatnya bisa diramalkan.

c. Implikasinya, pendidikan - melalui pendidiknya bisa menjadi alat kontrol sosial yang efektif dalam membentuk masyarakat baru.

d. Terdapat prinsip - prinsip pengajaran baru yang wajib untuk diterapkan pendidik di era transformasi digital saat ini, yaitu Keluar dari zona nyaman, bekerja dengan target atau capaian yang jelas, fokus memberikan aktivitas yang bermakna dan berdampak, menerima dan memberikan feedback berkualitas, 
dan Membentuk mental model seorang berkualifikasi ahli.

\section{DAFTAR PUSTAKA}

Brofenbrenner, U. (1979). The Ecology of Human Development, Cambridge, MA: Harvard University Press.

Gillin, J. L \& Gillin, J. P. (1948). Cultural Sociology (A revision of An Introduction to Sociology). New York: The Macmillan Company

Gordon, E. W. (2019). Strengthening Families, Communities, and Schools to Support Children's Development: Neighborhoods of Promise, Routledge.

Harper, C. L \& Leicht. Exploring Social Change: America and the World

Morrish, Ivor. (2017). The Sociology of Education: An Introduction. Routledge. London

William, H. A. (1985) . Antropologi Jilid 1, terjemahan R. G. Soekardijo. Surakarta: Erlangga.

https://arryrahmawan.net/prinsip-yangperlu-ditanamkan-pendidik-di-era-disruptif 